кандидат психологічних наук, доцент (Украйна, Слов'янськ, Державний вищий навчальний заклад "Донбаський державний педагогічний університет", вул. Батюка, 19)

VICTORIIA HRYNKO, candidate of psychological sciences, associate professor (Ukraine, Sloviansk, State Higher Educational Institution "Donbas State Pedagogical University",

ORCID: 0000-0001-9834-7181

\title{
Формування цифрової компетентності майбутніх учителів під час реалізації навчально-
} дослідницького проекту

\section{Developing Future Teachers' Digital Competence While Performing Learning and Research Project}

Дослідження спрямовано на вирішення актуальних завдань профьесійної підготовки майбутніх вчителів початкової школи, а сале фборлування та розвиток иифрової колпетентності, які відбуваються в результаті інтеграції розвитку когнітивних, креативних, комунікативних та колаборативних умінь. Метою наукової праці $е$ дослідження впливу використання цифбрових технологій на фбормування когнітивних, креативних, колунікативних та колаборативних умінь майбутніх учителів початкової школи під час реалізацї навчальнодослідницького проекту.

У статті описано організаційну структуру навчально-дослідницького проекту "Студентська наукова конфберениія", реалізованого під час вивчення курсу "Основи наукових досліджень", охарактеризовано види роботи з иифровими технологіями та иибровими ресурсали. Простежено динаміку зміни рівня сбормованості здатності використовувати иифрові освітні технології для розвитку когнітивних, креативних, колунікативних, колаборативних умінь майбутніх учителів початкової школи та мотивацї брати участь у науково-дослідницькій діяльності. $\quad$ У результаті проведеної роботи запропоновано ілплелентувати курс "Основи наукових досліджень" у формі навчально-дослідницького проекту, оскільки такий підхід мотивуе студентів до участі у науковій діяльності та сприяе активізацї процесу фборлування цифбрової компетентності.

Ключові слова: ииброва колпетентність, иифрові освітні технологї, науководослідницька діяльність, навчально-дослідницький проект, майбутні учителі початкової школи.

The experimental program is aimed at fulfilling the relevant targets of the future primary school teachers' professional training, in particular forming and developing the digital competence. The author claims that the future teachers' digital competence is formed as a result of integrating the cognitive, creative, communicative, and collaborative skills. The purpose of the scientific paper is studying the influence of the digital technology on the development of the future primary school teachers' cognitive, creative, communicative, and collaborative skills while performing learning and research project.

In the study the author uses the methods of questionnaire, survey, and observation, as well as the methods of analyzing, comparing, and generalizing the obtained experimental results.

While studying the course "Basis of Scientific Research" during the term, the learning and research project "Student Scientific Conference" has been realized. The aim of the project is modelling the process of scientific findings, using the digital technologies for developing the future primary school teachers' cognitive, creative, communicative, and collaborative skills. When implementing the project, the following forms of working with digital technologies and digital resources have been applied: working on the Internet, working with text editors, working with graphic editors and online services, mutual online cooperation, working with photo and video editors, working on the electronic social networking sites, and involving students from other higher educational institutions in participating in online learning.

The research results are presented in the form of comparative analysis of the indicators of the level of development of the future primary school teachers' cognitive, creative, communicative, and collaborative skills, which are gained at the initial stage (the beginning of the $4^{\text {th }}$ term in the academic year of 20152016) and the final stage of research (the end of the $4^{\text {th }}$ term in the academic year of 2015-2016).

It is noted that the use of digital technologies at all the stages of the project results in increasing the development of cognitive, creative, communicative, and collaborative skills, which are essential for the 
future teachers' professional activities in digital society.

The author proposes to introduce the course "Basis of Scientific Research" in the form of learning and scientific project, because such an approach contributes to enhancing the development of digital competence and encourages students to participate in scientific activities.

Key words: digital competence, digital educational technologies, scientific and research activities, learning and research project, future primary school teachers.

Вступ / Introduction. У результаті стрімкого розвитку цифрових технологій та інших об'єктивних причин освітній процес у закладах освіти не завжди відповідає вимогам суспільства, тому одним із провідних завдань професійної підготовки майбутніх вчителів е формування та розвиток цифрової компетентності.

Як зазначено в рекомендаціях Ради Свропи щодо визначення ключових компетентностей для навчання впродовж життя (2018), цифрова компетентність передбачае впевнене, критичне та відповідальне використання та взаємодію з цифровими технологіями для навчання, роботи та участі у суспільстві, що передбачае інформаційну грамотність, комунікацію та співпрацю, створення цифрового контенту, безпеку та розв'язання проблем.

Основою цифрової компетентності є навички використання цифрових технологій, засобів комунікації, управління, інтеграції, оцінки, створення та передачі інформації етично та на законних підставах задля активної участі у суспільстві інформації та знань. Цифрова компетентність вміщуе навички роботи в цифровому інформаційно-комунікаційному середовищі, розуміння і критичне оцінювання цифрового і медіа контенту, ефективне і безпечне використання цифрових технологій для вирішення різних професійних завдань (MoPED, 2018).

Вивчення складових цифрової компетентності дає нам підстави стверджувати, що цифрова компетентність майбутніх учителів формуеться в результаті інтегрованого розвитку когнітивних, креативних, комунікативних та колаборативних умінь.

Мета та завдання / Aim and Tasks. Метою наукової праці є дослідження впливу використання цифрових технологій на формування когнітивних, креативних, комунікативних та колаборативних умінь майбутніх учителів початкової школи в процесі реалізації навчальнодослідницького проекту.

Реалізація поставленої мети зумовила необхідність вирішення таких завдань:

- описати організаційну структуру навчально-дослідницького проекту «Студентська наукова конференщія», реалізованого під час вивчення курсу «Основи наукових досліджень»;

- охарактеризувати види роботи з цифровими технологіями та цифровими ресурсами під час виконання завдань проекту;

- простежити динаміку зміни рівня використання цифрових освітніх технологій для розвитку когнітивних, креативних, комунікативних та колаборативних умінь майбутніх учителів початкової школи, а також мотивації брати участь у науково-дослідницькій діяльності.

Методи / Methods. Дослідно-експериментальна робота здійснювалася на базі факультету початкової, професійної та технологічної освіти ДВНЗ «Донбаський державний педагогічний університет» (м. Слов'янськ, Україна). Усього дослідженням було охоплено 90 майбутніх учителів початкової школи, віком 19-29 років, які здобували першу вищу освіту за спеціальністю «Початкова освіта».

Дослідження здійснювалося впродовж IV семестру 2015-2016 н.р.:

1. Констатувальний експеримент (початок IV семестру 2015-2016 н.р.) передбачав анкетування студентів щодо виявлення рівня сформованості когнітивних, креативних, комунікативних та колаборативних умінь. Анкетування студентів проводилося на основі сучасного сервісу GoogleForms.

2. Відповідно до результатів досліджень та авторської концепції проектування цифрових освітніх технологій у навчанні майбутніх учителів початкової школи була розроблена програма формувального експерименту, що передбачала реалізацію навчально-дослідницького проекту «Студентська наукова конференція» під час вивчення курсу «Основи наукових досліджень».

Проведення формувального експерименту було підпорядковано меті: удосконалення навичок використання цифрових освітніх технологій для формування когнітивних, креативних, комунікативних та колаборативних умінь майбутніх учителів початкових класів. Реалізація визначеної мети здійснювалася шляхом виконання таких завдань:

- ознайомити студентів із освітніми можливостями цифрових технологій;

- навчити використовувати цифрові освітні технології як засіб наукових досліджень, навчання, обміну інформаційними повідомленнями, створення творчої продукції, комунікації та колаборації.

3. По завершенню формувального експерименту (кінець IV семестру 2015-2016 н.р.) було проведено підсумкове дослідження рівня сформованості когнітивних, креативних, комунікативних 
та колаборативних умінь.

Під час вивчення курсу «Основи наукових досліджень» був реалізований навчальнодослідницький проект «Студентська наукова конференція». Мета проекту: моделювання процесу наукового пошуку з використанням цифрових технологій для розвитку когнітивних, креативних, комунікативних та колаборативних умінь майбутніх учителів початкових класів. Проект передбачав реалізацію таких етапів:

1. Підготовчий етап включав: вивчення теоретичних основ науково-дослідницької діяльності; ознайомлення з умовами та вимогами реалізації проекту; обрання оргкомітету; розподіл обов'язків; узгодження дати проведення та теми конференції.

2. Етап організації проведення конференції включав: підготовку наукової статті, доповіді та презентації; розробку сценарія, виготовлення інформаційного листа, емблеми, оголошення та запрошень, програми конференції, сертифіката учасника, оформлення збірника матеріалів конференції; оформлення аудиторії; запрошення гостей; реестрацію заявок; підготовку технічного обладнання, брейк-кави, фото- та відеозабезпечення.

3. Підсумковий етап включав: оголошення результатів; нагородження учасників та висловлення подяки; оформлення папки 3 матеріалами для звіту на кафедрі; підготовка інформації про конференцію (стаття для ЗМI, повідомлення для сайту університету, фоото-звіт тощо).

Результатом проекту стало проведення наукової конференції та видання збірника матеріалів конференції в межах академічної групи з чітким виконанням загальноприйнятих вимог.

$\mathrm{y}$ процесі роботи над проектом були виконані такі види навчальної діяльності з цифровими технологіями та цифровими ресурсами:

1) Робота в мережі інтернет - пошук, аналіз інформації для написання наукової статті (Google пошук, GoogleScholar та ін.)

2) Робота з текстовими редакторами - підготовка статті, верстка збірника статей, звіту та ін. (GoogleДокументи, Microsoft Publisher, Microsoft Word та ін.)

3) Робота з графічними редакторами та онлайн-сервісами - підготовка інформаційного листа, оголошення, бейджів, запрошень, розробка обкладинки збірника праць, сертифікатів, подяк, грамот, презентацій, оформлення аудиторії (PowerPoint, Paint, Corel Draw, Adobe Photoshop, Canva, Crello, Editor та ін.).

4) Спільна робота онлайн - використання хмарних технологій для ефективної співпраці (GoogleDrive, OneDrive).

5) Робота з фото- та відео-редакторами та онлайн-сервісами - підготовка звіту та публікацій (Movavi Photo Editor, Kinemaster, PhotoDirect, PixArt, Fotor,Trello та ін.).

6) Робота в електронних соціальних мережах - анонс заходу, запрошення, висвітлення події (Facebook, Instagram).

7) Залучення студентів з інших вишів до онлайн участі в конференщії (Hangouts, Skype).

Теми конференщії були обрані студентами самостійно і відповідали їхнім інтересам та спеціалізації груп: «Інформаційне суспільство: виклики та реалії», «Організація та проведення музичних фестивалів», «Математика в мистецтві».

Результати / Results. Результати експерименту, спрямованого на реалізацію навчальнодослідницького проекту «Студентська наукова конференція» для формування когнітивних, креативних, комунікативних та колаборативних умінь майбутніх учителів початкових класів, представлені в порівняльному аналізі показників, отриманих на початковому (початок IV семестру 2015-2016 н.р.) та кінцевому етапах дослідження (кінець IV семестру 2015-2016 н.р.)

Діагностика рівня сформованості умінь та мотивації студентів до участі у науковій діяльності здійснювалася на основі аналізу відповідей на поставлені питання, об’еднані у п’ять блоків.

І блок. Діагностика рівня використання цифрових освітніх технологій для розвитку когнітивних умінь.

1.Оцініть рівень використання иифрових освітніх технологій у свойй навчальній діяльності, де 1 - ніколи не використовую, 2 - використовую дуже рідко, 3 - використовую рідко, 4 використовую часто, 5 - використовую дуже часто.

У результаті самооцінювання на початковому етапі дослідження студенти зазначили, що рівень використання ними цифрових освітніх технологій у навчальній діяльності $е$ недостатнім.

Протягом семестру значно виросла кількість студентів, які дуже часто використовують цифрові освітні технології у своїй навчальній діяльності (з $22 \%$ до $42 \%$ ); часто використовувати ці технології стали 36 \% (порівняно з 27 \% на початковому етапі), до того ж ця кількість збільшилася не тільки за рахунок тих, хто використовував цифрові освітні технології рідко, а й за рахунок тих, хто їх використовував дуже рідко. Відсоток останніх взагалі зменшився до нуля. Зауважимо, що сумарна кількість студентів, які використовують цифрові освітні технології у своїй навчальній 
діяльності часто і дуже часто, тобто, практично постійно, становить 78 \% (приріст становить 29 \%).

2.Які інтернет-ресурси Ви використовуєте при підготовиі рефбератів, наукових робіт, cmameŭ?

Наприкінщі семестру перелік використовуваних інтернет-ресурсів розширився, при цьому якісно, за рахунок більш серйозних джерел: GoogleScholar, сайти наукових журналів.

3.Які джерела інфбормації Ви вважаєте найбільш достовірнили? (Обрати один варіант відповіді).

- Все, що запропонуе пошукова система.

- Сайти з готовими редератами.

- Сайти освітньої тематики.

- Сайти наукових журналів та наукометричних баз.

Щодо достовірності джерел інформації, то на початку семестру суттева перевага була на боці практично готових матеріалів, які можна отримати без особливих зусиль на відповідних сайтах $(66,4 \%)$, лише 30 \% студентів зверталися до сайтів професійної спрямованості - освітньої тематики і тільки кожний двадцятий користувався наукометричними базами.

4.Якщо інфбормація з підручника для рефберату запозичена з сайту, яке посилання Ви poбите?

- На сайт, на якому викладено інформацію.

- На підручник.

- На сайт та на підручник.

Щодо посилань на джерела, які роблять студенти при підготовщі рефератів, слід зазначити, що на початку семестру ці посилання робилися, в основному, на сайт $(71,1 \%)$ та на підручник (20 \%), якщо було вказано окреме видання. На сайт і підручник, як правило, посилання робилися досить рідко (8,9\%).

ІІ блок. Діагностика використання цифрових освітніх технологій для розвитку креативних умінь.

1. Назвіть иифрові технологї̈, які Ви використовуєте для художнього офборллення плакатів?

Якщо на початку семестру студенти називали лише цифрові освітні технології PowerPoint, Paint, Photoshop, то наприкінщі семестру додалися онлайн-сервіси Canva, Crello, Editor, які вони вчилися використовувати при створенні плакатів.

2. Отрилуючи нове завдання щодо виготовлення творчого продукту

- Ви намагаєтесь використати знання, які вже маєте.

- Шукаете шляхи виконання новим способом.

- Діете залежно від обставин.

Щодо підходу до створення творчого продукту, на початку дослідження суттева перевага була на боці використання набутих знань, а пошуком нових рішень для цього переймалася вдвічі менша кількість студентів (31,1\% порівняно з 64,4\%). Наприкінці ж дослідження пошук нових рішень став пріоритетом для 53,3 \% студентів. Збільшення відбулося, в основному, за рахунок тих, хто відійшов від використання тільки вже відомих знань. Про це свідчить несуттева зміна кількості студентів, які діяли залежно від обставин (6,7 \% порівняно з 4,4 \%).

3. Для художнього оббормлення своєї роботи Ви використовуєте:

- готові шаблони з мережі Інтернет;

- готові шаблони редакторів;

- створюете власний продукт;

- діете залежно від обставин.

Для художнього оформлення своєї роботи на початку семестру готові шаблони редакторів та 3 мережі Інтернет використовували $65,6 \%$, а менш ніж третина їх віддавала перевагу створенню власного продукту, при цьому тільки 5 \% діяли залежно від обставин.

III блок. Діагностика використання цифрових освітніх технологій для розвитку колаборативних умінь.

1.Як часто виникае потреба у спільній роботі з одногрупниками під час навчальної діяльності? 1-ніколи, 2-дуже рідко, 3-рідко, 4-часто, 5-дуже часто.

На питання, як часто виникає потреба у спільній роботі з одногрупниками під час навчальної діяльності, на початку семестру тільки 10 \% студентів дали відповідь, що часто та дуже часто, а решта - 9 із 10 студентів - такої потреби практично не мали.

Наприкінці ж семестру потребу в спілкуванні з одногрупниками під час навчання мали майже 70 \% студентів, при цьому переважна більшість із них $(45,6 \%)$ - дуже часто. Співвідношення кількості студентів, які ніколи, дуже рідко або рідко мали потребу у спільній роботі 3 одногрупниками до кількості студентів, які таку потребу мали часто або дуже часто, змінилося 
суттево: від 9:1 до 1:2,2, що свідчить про наявний прогрес у цьому аспекті.

2.Під час виконання спільного завдання з одногрупниками Ви ділитесь інфборлацією та домовляетесь про розподіл обов'язків /завдань (обрати варіант, яким користуєтесь найчастіше):

- В аудиторії.

- В електронних соціальних мережах.

- Через електронну пошту.

- Використовуючи хмарні технології.

- Через мобільний зв'язок.

На початку IV семестру в процесі виконання спільного завдання з одногрупниками студенти найчастіше ділилися інформацією та домовлялися про розподіл обов'язків в аудиторії при безпосередньому спілкуванні та за допомогою мобільного зв'язку чи соціальних мереж (разом $92,3 \%$, серед них 45,6 \% - в аудиторії та $35,6 \%$ - в електронних соціальних мережах).

3. Назвіть ииброву технологію, яка $е$ найбільш вживана Вами для взаємодії з одногрупникали та однокурсниками? Поясніть ї̈ переваги.

На початку семестру майже всі опитані найбільш вживаною технологіею комунікації 3 одногрупниками назвали електронні соціальні мережі, наприкінці семестру додалися групові чати та коментарі у спільних документах.

IV блок. Діагностика використання цифрових освітніх технологій для розвитку комунікативних умінь.

1.Чи виникають проблеми спілкування з одногрупниками в інформаційному просторі в процесі підготовки спільного завдання?

- Hi, завжди все добре.

- Інколи бувають непорозуміння.

- Досвіду спільної роботи не маю.

На питання, чи виникають проблеми спілкування з одногрупниками в інформаційному просторі під час підготовки спільного завдання, відповідь «завжди все добре» на початку семестру дали $22,2 \%$, «Інколи бувають непорозуміння» - 11,1\%. Наприкінці семестру суттєвих змін у відповідях на ці питання не сталося. Щодо наявності досвіду спільної роботи протягом семестру відбулися значні зміни: якщо на початку семестру $66,7 \%$ респондентів досвіду виконання відповідної діяльності не мали, то наприкінці його таких відповідей було лише 11,1 \%.

2.Встановіть відповідність між записали (1-4) та прізвищали авторів $(A-\Gamma)$ :

1.Повідомлення, що надсилаються вам від невідомих людей або організацій, яким ви не давали на це дозволу

А.Флейм

2.Процес, який іноді виникае при спілкуванні в Інтернеті, «словесна війна». Це зненацька виникле бурхливе обговорення, у процесі якого учасники звичайно забувають про первісну тему, переходять на особистості й не можуть зупинитися.

3.Повідомлення в інтернет-форумах великі за обсягом й не наповнені ніякою корисною інформацію

4.Повідомлення не по темі обговорення або поштового розсилання. Учасники інтернет-співтовариств починають спілкуватися на другорядні або на зовсім відвернені теми, відмінні від тіеї, що оголошена в заголовку поточного обговорення

Б. Офртоп

В. Спам

Г. Флуд

На початку семестру відповідність правильно встановили $-24,4 \%$, а наприкінці семестру $62,2 \%$ опитуваних.

3.Напишіть текст електронного листа викладачу з проханнял перевірити рефберат.

При аналізі тексту листа було враховано, чи була вказана тема листа, чи е вітання та звернення, уточнення від кого лист, як сформульоване прохання. На початку семестру лише $6,7 \%$ листів повністю відповідало вимогам мережевого етикету, у $26,7 \%$ листів норми дотримувались частково, а 66,6\% листів лише передавали сутність прохання. Після реалізації навчального проекту кількість листів із повним дотриманням вимог зросла до $23,3 \%$, часткова відповідність вимогам була продемонстрована у 57,8 \%, решта 18,9\% так і залишилася на початковому рівні. Отже, у 3,5 рази зменшилася кількість студентів, які не володіють правилами мережевого етикету при спілкуванні, при цьому практично у стільки ж разів збільшилася кількість тих, чиї листи повністю відповідають вимогам.

V блок. Діагностика рівня мотивації брати участь у науково-дослідницькій діяльності.

1. Чи виконували Ви нові наукові завдання, навчаючись в університеті, порівняно зі школою?

- Завдання такого ж рівня.

- Завдання відрізняються від шкільних за складністю.

- Виконували нові види завдань, причому значно вищого рівня складності (навести приклади). 
Не помічали різниці між науковими завданнями, що виконувалися у школі та в університеті на початку семестру 22,2 \% студентів; $55,5 \%$ звернули увагу на більш високий рівень цих завдань і лише третина опитуваних помітили і нові форми, і значно вищий рівень складності пропонованих навчальних завдань наукового характеру. Слід зауважити, що навести приклади змогли лише $10 \%$ із них.

Протягом семестру відповіді на ці питання зазнали суттевих змін: 16,7\%, як і раніше, вважали, що наукові завдання того ж рівня складності, як і в школі; вдвічі більша кількість студентів відмітили підвищення складності завдань, а половина студентів курсу не тільки зазначила, що нові форми мають місце, а навіть назвала їх, надавши від одного до трьох прикладів.

2. Чи е у Вас бажсання зайлатися науково-дослідницькою роботою (НДР)?

- Не можу точно сказати.

- Бажання займатися НДР е, бо за це можливе заохочення з боку викладачів.

- Бажання займатися НДР є, бо це допоможе реалізувати себе у майбутньому.

На початку семестру переважна більшість студентів $(64,4 \%)$ не змогла визначитися, чи має вона бажання займатися науково-дослідницькою роботою; хотіли б цим займатися за заохочення 17,8 \% і стільки ж мали таке бажання із міркувань про успішну реалізацію себе у майбутньому.

Заняття, проведені впродовж семестру, зокрема 3 «Основ наукових досліджень», суттево вплинули на зміну пріоритетів у виборі відповідей: не змогли визначитися тільки 15,6 \%, а серед бажаючих займатися НДР, переважали ті, хто розраховував на кращу самореалізацію в майбутньому (55,5 \% проти $28,9 \%$, які б хотіли займатися наукою за заохочення).

3. Яким чином, на Вашу думку, слід підсилювати бажання зайлатися наукою?

- Обирати для дослідження теми, які цікавлять студентів.

- Залучати студентів до організації наукових заходів.

- Виконувати спільні дослідження з викладачами, щоб студенти могли навчатися науковій діяльності.

На перше місце серед аргументів, що сприяли б підсиленню бажання займатися наукою, на початку IV семестру студенти поставили цікаві для дослідження теми (84,4\%); 8,9 \% із них вважали за потрібне залучення до організації наукових заходів, а решта (6,7 \%) висловилися на користь спільних із викладачами досліджень.

Реалізація навчально-дослідницького проекту «Студентська наукова конференція» під час вивчення курсу «Основи наукових досліджень», без сумніву, сприяла тому, що наприкінці семестру головним чинником впливу на розвиток бажання займатися наукою стало залучення студентів до організації наукових заходів (68,9\%); $21,1 \%$ студентів висловилися за спільні з викладачами дослідження, а решта (10 \%) віддали перевагу цікавим темам.

Слід зауважити, що значна більшість респондентів дописували в анкетах, що вибір одного 3 варіантів не означає заперечення інших і пропонували свій варіант відповіді: «підтримую всі три варіанти».

Обговорення / Discussion. Особливого значення для формування когнітивних, креативних, колаборативних і комунікативних умінь майбутніх учителів початкової школи набувае широке запровадження у освітній процес цифрових технологій. До проблеми інформатизації освітнього процесу закладів вищої освіти в цілому та підготовки вчителя початкової школи зверталися вітчизняні (В. Биков, М. Лещенко, Н. Морзе, Г. Скрипка, Л.Тимчук та ін.) та зарубіжні (В. Allen, Afari-Kumah, H. Caple, K. Coleman, Y. Hsu, J. Lee, T. Nguyen та ін.) науковці.

Ми погоджуемося з позиціею зарубіжних дослідників J. Lee i Y. Hsu (2002), які стверджували, що достатній рівень сформованості когнітивних умінь студентів позитивно впливае на їхню здатність оріентуватися в мережі та синтезувати знання з різних інформаційних джерел для виконання комплексних і складних завдань. Проте, як зазначають Afari-Kumah i Tanye (2009), головна проблема користування інтернет-ресурсами полягає в тому, що студенти копіюють чужі думки і висловлювання. Ця проблема виникає як результат підвищення впевненості в собі, коли студенти користуються новітніми цифровими технологіями. Тому завдання викладача полягає в забезпеченні глибшого розуміння студентами правил користування інтернет-ресурсами шляхом запровадження низки завдань для розвитку когнітивної гнучкості. Отже, беручи до уваги дослідження вищезгаданих авторів, ми можемо стверджувати, що система заходів, запроваджена впродовж експериментального періоду виявилася ефективною. Адже, протягом семестру рівні сформованості умінь використовувати цифрові технології для розвитку когнітивних умінь студентів зазнали суттевих змін. Це помітно по збільшенню кількості студентів, які часто використовують у своїй навчальній діяльності цифрові освітні технології; по якісному розширенню переліку використовуваних інтернет-ресурсів; по перевазі, яку студенти надають сайтам освітньої тематики та наукометричним базам та по більш детальній і раціональній характеристиці джерел 
інформації.

Подальший аналіз праць західних науковців щодо підвищення рівня сформованості креативних умінь студентів шляхом застосування цифрових технологій дозволяе стверджувати, що наше дослідження є співзвучним із дослідженнями В. Allen, H. Caple, K. Coleman i T. Nguyen (2012), які доводять, що виконання студентами творчих завдань, що передбачають редагування медіатекстів, сприяе розвитку креативних умінь.

Отже, говорячи про використання цифрових освітніх технологій для розвитку креативних умінь, слід зазначити, що протягом семестру студенти навчилися користуватися цифровими освітніми технологіями, до яких вони зверталися під час створення творчих продуктів та художнього оформлення навчального контенту. Для переважної більшості студентів пріоритетом став пошук нових рішень при виготовленні творчого продукту і майже в 1,5 рази збільшилося кількість студентів, які стали використовувати для художнього оформлення своєї роботи продукти власного виробництва.

Вітчизняні та зарубіжні дослідники Н. Морзе (2018), Г. Скрипка (2016), C. Lewin (2015), J. Voogt (2013), вивчаючи проблему навчальної взаємодії студентів засобами цифрових технологій, звернулися до питання вдосконалення колаборативних умінь студентів, зокрема через розроблення системи завдань, метою яких е активізація корпоративної діяльності та досягнення навчальних цілей, а не переслідування особистісних неформальних інтересів.

Діагностика використання цифрових освітніх технологій для розвитку колаборативних умінь засвідчила суттеве зростання протягом IV семестру кількості студентів, які часто або дуже часто мали потребу в спілкуванні з одногрупниками під час навчальної діяльності. Також змінилися пріоритети спілкування студентів - переважно у бік сучасних інформаційних технологій електронних соціальних мереж, електронної пошти та хмарних технологій.

Діагностика використання цифрових освітніх технологій для розвитку комунікативних умінь засвідчила наявність позитивних змін щодо досвіду спільної роботи з одногрупниками в інформаційному просторі та правильного розуміння змісту термінів, які зустрічаються під час спілкування на форумах, у блогах або соціальних мережах. Також значно підвищився рівень володіння правилами мережевого етикету у спілкуванні з одногрупниками та викладачами.

Слід наголосити, що зазначені твердження е співзвучними з дослідженнями D. Di Giacom, J. Raniery, P Lacasa (2017), які довели, що застосування цифрових технологій підвищуе якість освітньої підготовки студентів і загальну культуру спілкування в щілому.

Зростання рівня мотивації до здійснення наукової діяльності є якісним показником успішності реалізації навчально-дослідницького проекту, що підтверджуе аналіз наукових знахідок групи зарубіжних дослідників на чолі з А.-M. Gasaymeh (2017), які дійшли висновку, що саме застосування цифрових технологій в формальній освіті сприяе підвищенню рівня мотивації студентів, урізноманітненню форм навчання та зростанню результативності навчальнодослідницької діяльності.

Висновки / Conclusions. Використання інформаційних повідомлень та знань є основою сучасного суспільства, активне розповсюдження медіа- та цифрових технологій має неабиякий вплив на всі сфери життя людини. Тому в інформаційному суспільстві необхідно формувати вміння, які допоможуть забезпечити якісне та безпечне життя. Інформатизація всіх сфер життя привела до зміни ролі вчителя, появи нових форм та методів підготовки майбутніх педагогів. Використання цифрових технологій в освітньому процесі закладу вищої освіти допомагає створити інноваційне навчальне середовище, об’еднати педагогічні технології, проводити цікаві заняття, сприяти створенню навчальної колаборації студентів та мотивувати всіх учасників до пошуку нових рішень начальних завдань.

Реалізація навчально-дослідницького проекту «Студентська наукова конференція» дала можливість моделювання наукового пошуку 3 використанням цифрових технологій. Запровадження цифрових технологій на всіх етапах проекту сприяло підвищенню рівня сформованості когнітивних, креативних, колаборативних, комунікативних умінь, необхідних для професійної діяльності майбутніх педагогів у цифровому суспільстві.

Вважаємо за доцільне проводити курс «Основи наукових досліджень» у формі навчальнодослідницького проекту. Такий підхід сприяе активізації формування цифрової компетентності, мотивуе студентів до участі у науковій діяльності. 
Список використаних джерел і літератури / References:

1.Скрипка, Г. (2016). Формування в учнів навичок ХХІ століття засобами інформаційно-комунікаційних технологій. Інфборлаційні технологї $i$ засоби навчання, 4(54), 99-107. DOI: https://doi.org/10.33407/itlt.v54i4.1410. / Skrypka, H. (2016). Formuvannia v uchniv navychok XXI stolittia zasobamy informatsiino-komunikatsiinykh tekhnolohii [Developing Students Skills of the XXI Century by Means of ICT]. Informatsiini tekhnolohii s zasoby navchannia, 4(54), 99-107. DOI: https://doi.org/10.33407/itlt.v54i4.1410 [in Ukrainian].

2.Afari-Kumah, E., \& Tanye, H. A. (2009). Tertiary students' view on information and communications technology usage in Ghana. Journal of Information Technology Impact, 9(2), 81-90 [in English].

3.Allen, B., Caple, H., Coleman, K. \& Nguyen, T. (2012). Creativity in Practice: Social Media in Higher Education. Proceedings of ASCILITE - Australian Society for Computers in Learning in Tertiary Education Annual Conference 2012. (pp. 15-20). Willington: Australasian Society for Computers in Learning in Tertiary Education [in English].

4.Building the Digital Competence Teacher Profile by Innovative Teaching Instruments (MoPED). (2018). Kyiv: Borys Grinchenko Kyiv University. URL: http://moped.kubg.edu.ua/wpcontent/uploads/2014/03/MoPED_D1.4_DigComsummary.pdf [in Ukrainian].

5.Di Giacomo, D., Ranieri, J., \& Lacasa, P. (2017). Digital Learning as Enhanced Learning Processing Cognitive Evidence for New Insight of Smart Learning. Frontiers in Psychology, 8. DOI: 10.3389/fpsyg.2017.01329 [in English].

6.Gasaymeh, Al-Mothana, M., Adnan, Moghrabi, Khaldun, \& Al-Ghonmein, Ali Mohammad. (2017). University Students' Perceptions of the Use of Digital Technologies in their Formal Learning: A Developing Country Perspective. International Journal of Learning and Development, 7, 149-164. DOI: 10.5296/ijld.v7i3.11666 [in English].

7.Lee, J.J. \& Hsu, Y. (2002). Web navigation: The role of Metaphor, Concept Map and Individual Differences. In P. Barker \& S. Rebelsky, (Eds.). Proceedings of ED-MEDIA, 2001 World Conference on Educational Multimedia, Hypermedia \& Telecommunications (pp. 1000-1001). Norfolk, VA: Association for the Advancement of Computing in Education [in English].

8.Lewin, C. \& McNicol, S. (2015). Supporting the Development of 21st Century Skills through ICT. In T. Brinda, N. Reynolds, R. Romeike, \& A. Schwill (Eds.). KEYCIT 2014: Key competencies in informatics and ICT (pp. 98-181) [in English].

9.Morze N., Gladun M., Vember V., Buinytska O. (2018). Building the Digital Competence Teacher Profile by Innovative Teaching Instruments. Kyiv: Borys Grinchenko Kyiv University [in English].

10.Proposal for a Council Recommendation on Key Competences for Lifelong Learning. (2018). URL: https://ec.europa.eu/education/education-in-the-eu/council-recommendation-on-key-competences-for-lifelonglearning_en [in English].

11.Voogt, J., Erstad, O., Dede, C., \& Mishra, P. (2013). Challenges to Learning and Schooling in the Digital Networked World of the 21st Century. Journal of Computer Assisted Learning, 29, 403-413 [in English].

Дата надходження статті: «17» квітня 2019 р.

Стаття прийнята до друку: «14» травня 2019 р.

Гринько Вікторія - доцент кафедри природничо-математичних дисциплін та інформатики в початковій освіті Державного вищого навчального закладу «Донбаський державний педагогічний університет», кандидат психологічних наук, доцент

Hrynko Viktoriia - assistant professor of the department of natural and mathematical sciences and informatics in elementary education of State Higher Educational Institution «Donbas State Pedagogical University», candidate of psychological sciences, associate professor

\section{Цитуйте ию статтю як:}

Гринько, В. (2019). Формування компетентності майбутніх учителів реалізації навчально-дослідницького Педагогічний дискурс, 26, 77-84.
Cite this article as:

цифрової Hrynko, V. (2019). Developing Future Teachers' під час Digital Competence While Performing Learning and проекту. Research Project. Pedagogical Discourse, 26, 77-84. 